Proc. Inđian Acad. Sci., Vol. 87 A (E \& P Sciences-4), No. 11, November 1978, pp. 255-261, (C) printed in India

\title{
Mineralogy of the fuchsites from Gattihosahalli, Chitradurga District
}

\author{
T C DEVARAJU and $K$ S ANANTHA MURTHY \\ Department of Geology, Karnatak University, Dharwar 580003
}

MS received 2 September 1978

\begin{abstract}
The fuchsites described here occur in the lower portions of a precambrian quartzite bed, which typically encloses small bands and lenses of barytes. Of the two fuchsites studied, one occurs in the main relatively fine grained quartzite and the other forming one of the small schistose segregations in the quartzite. While the commonly measured axial angles average $34^{\circ}$ and $32^{\circ}$, small angles of $14^{\circ}$ and $19^{\circ}$, which are possibly related to the formation of the mineral under high pressure, have been recorded in both the fuchsites. There is a close similarity in $\mathrm{x}$-ray powder pattern between the two fuchsite samples studied and between these and muscovite. This observation is in accordance with the interpretation that fuchsites exhibit the same two layered mica structure as muscovite $2 \mathrm{M}_{1}$. Chemically the fuchsites of Gattihosahalli are closely similar to the one reported from Manitoba and the cell contents are comparable to di-octahedral micas of muscovite character with $\mathrm{Cr}$ substituting for octahedarl Al. It is inferred that the fuchsites of Gattihosahalli are of sedimentary origin and the constituents required for their formation were all present in the shaly component of the sandstone or were partly or completely supplied by volcanic exhalations.
\end{abstract}

Keywords. Fuchsites; 2-layer mica structure; sedimentary; volcanic exhalation.

\section{Introduction}

The two fuchsite mica samples described here are from the attractively green coloured portions of the quartzite bed which encloses the recently discovered precambrian bedded barytes deposits of the area (Radhakrishna and Srinivasaiah 1974). The fuchsite quartzite forms the western or the lower portion of the bed (interestingly most of the barytes beds are also located in this portion), the bulk of which is buff white sericite-bearing quartzite. The fuchsite quartzite of the area is quarried at many places for ornamental stone and in several of these quarries the unmistakable interbedded sedimentary character of quartzite and baryte is exposed. The two samples used in this study are collected from the quarry on the southern slope of the low mound situated to the west of Gattihosahalli. The geological succession exposed in the mound is as shown in figure 1.

\section{Petrography}

Of the four samples collected for the present study, three represented the main fuchsite quartzite, which contains on an average 89 and 11 modal percents of quartz 


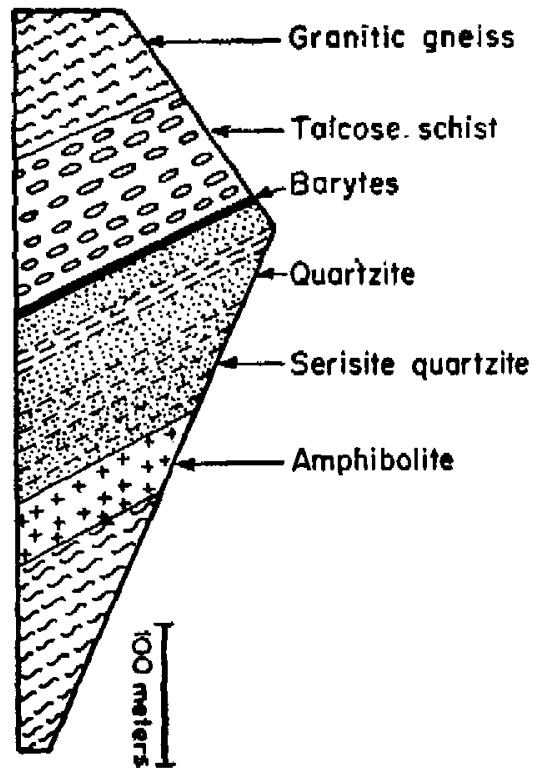

Figure 1. Geological section across the small mound west of Gattihosahalli.

and fuchsite respectively. These are comparatively fine grained (the average fuchsite spangle in these is $0.7 \mathrm{~mm} \times 0.5 \mathrm{~mm}$ ), lighter green coloured and only moderately foliated. The fourth sample, designated here as fuchsite-quartz schist, is relatively coarse grained (the average size of fuchsite spangles is $1.2 \mathrm{~mm} \times 0.05 \mathrm{~mm}$ ), bright green coloured, strongly foliated and entiched (with an average of $23 \%$ modal fuchsite) in fuchsite. The fuchsite-quartz schist forms small segregation-like lenses and patches in the fuchsite quartzite.

In thin section, the rocks show abundant (an average of 89 and 76 modal percent quartz in the fuchsite quartzite and fuchsite-quartz schist respectively), interlocking anhedral grains of quartz, distinctly bluish green coloured scales and anhedral plates of fuchsite and sporadically distributed small shapeless grains of rutile. Blades of kyanite $\left(2 v_{x} 85^{\circ}\right)$ showing high relief occur in isolated lenses and patches only in the fuchsite-quartz schist specimen. Both quartz and fuchsite, although devoid of inclusions, always show undulose extinction, which it is strongly marked in the former.

\section{Optical characters}

The important optical properties determined (see table 1) for the fuchsite of the quartzite and the schist show the following features.

(i) A significant variation in axial angle values $\left(27^{\circ}\right.$ to $43^{\circ}$ in quartzite and $29^{\circ}$ to $36^{\circ}$ in schist) and the presence of crystals with small axial angles ( $14^{\circ}$ or less in quartzite; $24^{\circ}, 19^{\circ}$ or less in schist). The variation in axial angles is possibly related to the fluctuation in metamorphic conditions and the small angles are correlated with the formation of the mica under high pressure (the latter part of the interpretation is supported by the occurrence of kyanite) (see also Whitmore et al 1946). 
Table 1. Optical properties of fuchsites.

\begin{tabular}{lll}
\hline & Fuchsite from quartzite & Fuchsite from schist \\
\hline $2 \mathrm{~V}_{x}$ & $32^{\circ}, 34^{\circ}, 31^{\circ}, 27^{\circ}, 43^{\circ}, 30^{\circ}, 30^{\circ}$ & $32^{\circ}, 28^{\circ}, 32^{\circ}, 35^{\circ}, 32^{\circ}$ \\
& $\left(\right.$ Average $\left.34^{\circ}\right)$ & $36^{\circ}, 32^{\circ}, 32^{\circ}, 29^{\circ}, 31^{\circ}$ \\
& Also $14^{\circ}$ & $31^{\circ}$, \\
& & $($ Average 32 $)$ \\
$\gamma$ & 1.6008 & Also $24^{\circ}$ and $19^{\circ}$ \\
$\beta$ & 1.5980 & 1.6102 \\
$a$ & 1.5688 & 1.6070 \\
$(y-a)$ & $0-032$ & 1.5747 \\
& & 0.0355 \\
\hline
\end{tabular}

Pleochrism; $X=$ Light emerald green; $Y==$ green; $Z=$ emerald green

(ii) The higher refractive index and birefrengence of the schist fuchsite, with lower $\mathrm{Cr}$ content, than the quartzite fuchsite, with higher $\mathrm{Cr}$ content. This observation is apparently contrary to what has been reported by Whitmcre et al (1946) and Deer et al (1962).

\section{X-ray study}

The x-ray powder data (table 2, figures 2 and 3 ) obtained separately for the fuchsite of quartzite and schist of the area reveals a close similarity not only between these two samples but also between these and the muscovite described by Hendricks and Jefferson (1939) (see table 2, No. 1). The latter part of the observation is in accordance with the opinion of Whitmore et al (1946) that fuchsites exhibit the same twolayer mica structure as that characteristic of muscovite $2 \mathrm{M}_{1}$.

\section{Chemistry}

Chemically the fuchsite of quartzite (No. 1) differs from that of schist (No. 2) in containing more of $\mathrm{Al}_{2} \mathrm{O}_{3}$ and $\mathrm{Cr}_{2} \mathrm{O}_{3}$ and less of $\mathrm{SiO}_{2}$ and $\mathrm{K}_{2} \mathrm{O}$ (table 3). A somewhat higher soda content of both the analysed fuchsite is a distinctive feature. Otherwise, the two analysed fuchsite are similar to each other; their compositions are well within the range recorded for the mineral by different workers (Whitmore et al 1946; Deer et al 1962; Sadashivaiah and Karisiddaiah 1976), and are akin to the one reported from Manitoba (table 3, No. 3). The minor difference in composition between the analysed samples of Gattihosahalli is believed to be inherent, related to the inhomogeneity in the compositions of the sedimentary rock (argillaceous sandstone) from which they are derived. The cell contents calculated on the basis of $24(\mathrm{O}, \mathrm{OH})$ are in accordance with the classification of the fuchsites as di-octahedral micas (Deer et al 1962), closely similar to muscovite, with $\mathrm{Cr}$ presumably replacing octahedral $\mathrm{Al}$ of muscovite. 
Table 2. X-ray powder data of fuchsites

\begin{tabular}{|c|c|c|c|c|c|c|}
\hline \multicolumn{3}{|c|}{1} & \multicolumn{2}{|c|}{2} & \multicolumn{2}{|c|}{3} \\
\hline$I$ & $h k l$ & $\mathrm{~d} \boldsymbol{A}$ & $I$ & $\mathrm{~d} \AA$ & $I$ & $d \AA$ \\
\hline 95 & 002 & 9.95 & 82 & $9 \cdot 880$ & 73 & 9.935 \\
\hline- & - & - & - & - & 4 & $5 \cdot 478$ \\
\hline 30 & 004 & 4.97 & 50 & 4.963 & 88 & $4 \cdot 966$ \\
\hline 20 & 110 & $4 \cdot 47$ & 3 & 4.475 & 3 & $4 \cdot 452$ \\
\hline 4 & 110 & $4 \cdot 30$ & 4 & $4 \cdot 264$ & 6 & $4 \cdot 246$ \\
\hline 4 & 022 & $4 \cdot 11$ & - & - & 1 & $4 \cdot 080$ \\
\hline 6 & 112 & 3.95 & - & - & 1 & 3.974 \\
\hline 14 & $11 \overline{3}$ & $3 \cdot 88$ & 3 & 3.875 & 3 & $3 \cdot 870$ \\
\hline 18 & 023 & 3.73 & 4 & 3.720 & 4 & $3 \cdot 714$ \\
\hline- & - & - & 3 & 3.656 & 7 & $3 \cdot 662$ \\
\hline 20 & $11 \overline{4}$ & 3.48 & 14 & $3 \cdot 466$ & 17 & $3 \cdot 465$ \\
\hline 25 & 024 & $3 \cdot 34$ & - & - & - & - \\
\hline 100 & 006 & $3 \cdot 32$ & 92 & $3 \cdot 312$ & 86 & 3.330 \\
\hline 30 & 114 & $3 \cdot 19$ & 8 & $3 \cdot 190$ & 6 & $3 \cdot 195$ \\
\hline 2 & 115 & $3 \cdot 12$ & - & - & - & - \\
\hline 35 & 025 & 2.987 & 10 & 2.981 & 11 & 2.984 \\
\hline 25 & 115 & 2.859 & 9 & 2.851 & 7 & $2 \cdot 851$ \\
\hline 20 & $11 \overline{6}$ & 2.789 & 6 & 2.782 & 6 & $2 \cdot 781$ \\
\hline 16 & $13 \mathrm{~T}$ & 2.596 & - & - & - & - \\
\hline 55 & $20 \overline{2}$ & $2 \cdot 566$ & 10 & $2 \cdot 561$ & 6 & $2 \cdot 561$ \\
\hline 8 & 008 & $2 \cdot 505$ & - & - & - & - \\
\hline 14 & 132 & 2.491 & 24 & $2 \cdot 481$ & 35 & 2.483 \\
\hline 8 & 133 & 2.465 & - & - & - & - \\
\hline 8 & 202 & $2 \cdot 450$ & - & - & 3 & 2.456 \\
\hline 10 & $20 \overline{4}$ & $2 \cdot 398$ & $\mathbf{3}$ & 2.399 & - & - \\
\hline 25 & 133 & $2 \cdot 384$ & - & - & 2 & $2 \cdot 383$ \\
\hline 10 & 134 & $2 \cdot 254$ & - & - & - & - \\
\hline - & - & - & 2 & $2 \cdot 851$ & 2 & $2 \cdot 280$ \\
\hline 4 & 135 & $2 \cdot 236$ & 2 & $2 \cdot 247$ & 2 & $2 \cdot 235$ \\
\hline 8 & 221,204 & $2 \cdot 208$ & 3 & $2 \cdot 195$ & 2 & $2 \cdot 202$ \\
\hline 4 & $22 \overline{3}$ & $2 \cdot 189$ & - & - & - & - \\
\hline 16 & $20 \overline{6}$ & 2.49 & - & - & - & - \\
\hline 20 & 135 & $2 \cdot 132$ & 6 & $2 \cdot 128$ & 3 & $2 \cdot 127$ \\
\hline 4 & 223 & 2.070 & 4 & 2.095 & - & - \\
\hline 6 & 044 & 2.053 & 8 & 2.045 & - & - \\
\hline 45 & 00,10 & 1.993 & 100 & $1 \cdot 985$ & 100 & 1.986 \\
\hline 10 & 224,045 & 1.972 & - & - & - & - \\
\hline 6 & 206 & 1.951 & - & - & - & - \\
\hline 4 & $22 \overline{6}$ & 1.941 & - & - & - & - \\
\hline 2 & $20 \overline{8}$ & 1.894 & - & - & - & - \\
\hline 4 & 046 & 1.871 & - & - & - & - \\
\hline 4 & - & 1.822 & 4 & 1.785 & 5 & 1.8200 \\
\hline 4 & 228 & 1.746 & 3 & 1.727 & 2 & $1 \cdot 726$ \\
\hline - & - & - & 4 & 1.673 & - & - \\
\hline- & - & - & 9 & $1 \cdot 656$ & 7 & $1 \cdot 658$ \\
\hline- & - & - & 5 & 1.641 & 6 & 1.645 \\
\hline- & - & - & 2 & 1.553 & $\ldots$ & - \\
\hline- & - & - & 3 & 1.540 & 3 & 1.543 \\
\hline- & - & - & 5 & 1.518 & 5 & 1.520 \\
\hline - & - & - & 4 & 1.505 & 3 & 1.496 \\
\hline- & - & 一 & 3 & $1 \cdot 447$ & 4 & 1.450 \\
\hline
\end{tabular}

1. Muscovite-2M $\mathrm{M}_{1}$. Reproduced from ASTM card 6-0263: CuKa radiation Ni filter.

2 \& 3. Fuchsites from Gattihosahalli;

(2) from the quartzite and (3) from schist (see under table 3 for further details); CuKa Radiation, Ni filter, $30 \mathrm{KVP}, 15 \mathrm{~mA}$ and chart speed $10 \mathrm{~mm} / \mathrm{min}$. 
Table 3. Chemical analysis of fuchsites.

\begin{tabular}{|c|c|c|c|c|c|c|}
\hline & \multicolumn{2}{|c|}{1} & \multicolumn{2}{|c|}{2} & \multicolumn{2}{|l|}{3} \\
\hline $\mathrm{SiO}_{2}$ & \multicolumn{2}{|c|}{43.94} & \multicolumn{2}{|c|}{$45 \cdot 55$} & \multicolumn{2}{|l|}{45.97} \\
\hline $\mathrm{Al}_{2} \mathrm{O}_{4}$ & \multicolumn{2}{|c|}{$34 \cdot 58$} & \multicolumn{2}{|c|}{$32-73$} & \multicolumn{2}{|l|}{31.67} \\
\hline $\mathrm{TiO}_{2}$ & \multicolumn{2}{|c|}{0.24} & \multicolumn{2}{|c|}{0.29} & \multirow{2}{*}{$4 \cdot 81$} & \\
\hline $\mathrm{Cr}_{2} \mathrm{O}_{2}$ & \multicolumn{2}{|c|}{3.90} & \multicolumn{2}{|c|}{$3 \cdot 14$} & & \\
\hline $\mathrm{Fe}_{2} \mathrm{O}$ & & & \multirow{2}{*}{\multicolumn{2}{|c|}{$\begin{array}{l}1.18 \\
0.19\end{array}$}} & 2.56 & \\
\hline $\mathrm{FeO}$ & \multicolumn{2}{|c|}{$0 \cdot 19$} & & & \multicolumn{2}{|l|}{0.53} \\
\hline $\mathrm{MnO}$ & \multicolumn{2}{|c|}{0.07} & \multicolumn{2}{|c|}{0.08} & \multicolumn{2}{|l|}{-} \\
\hline $\mathrm{MgO}$ & \multicolumn{2}{|c|}{1.90} & \multicolumn{2}{|c|}{$2-04$} & \multicolumn{2}{|l|}{$0 \cdot 31$} \\
\hline $\mathrm{CaO}$ & \multicolumn{2}{|c|}{0.56} & \multicolumn{2}{|c|}{0.34} & \multicolumn{2}{|l|}{0.15} \\
\hline $\mathrm{Na}_{2} \mathrm{O}$ & \multicolumn{2}{|c|}{1.88} & \multicolumn{2}{|c|}{$1+87$} & \multicolumn{2}{|l|}{1.03} \\
\hline $\mathrm{K}_{2} \mathrm{O}$ & \multicolumn{2}{|c|}{$7 \cdot 44$} & & & 9.07 & \\
\hline $\mathrm{H}_{2} \mathrm{O}^{+}$ & & & & & $3 \cdot 48$ & \\
\hline $\mathrm{H}_{8} \mathrm{O}^{-}$ & & & & & 0.51 & \\
\hline Total & & & 100 & & $100 \cdot 09$ & \\
\hline & Numbe & ions & le basis & 40,0 & & \\
\hline & 1 & & 2 & & 3 & \\
\hline $\mathbf{S i}$ & 5.924 & 8.00 & $6 \cdot 143$ & $8 \cdot 00$ & 6.268 & 8.00 \\
\hline $\mathrm{AI}$ & 2.076 & & 1.857 & & 1.732 & \\
\hline Al & 3.420 & & 3.347 & & $3 \cdot 360$ & \\
\hline $\mathrm{Ti}$ & 0.024 & & 0.029 & & & \\
\hline $\mathrm{Cr}$ & 0.416 & & 0.334 & & 0.518 & \\
\hline $\mathrm{Fe}^{+3}$ & 0.120 & $4 \cdot 39$ & 0.120 & $4 \cdot 27$ & 0.262 & $4 \cdot 26$ \\
\hline $\mathrm{Fe}^{+2}$ & 0.021 & & 0.021 & & 0.061 & \\
\hline Mn & 0.008 & & 0.009 & & & \\
\hline $\mathbf{M g}$ & 0.382 & & 0.410 & & 0.063 & \\
\hline $\mathrm{Ca}$ & 0.081 & & 0.049 & & 0.022 & \\
\hline $\mathrm{Na}$ & 0.491 & 1.85 & 0.489 & $2 \cdot 11$ & 0.272 & 1.87 \\
\hline $\mathrm{K}$ & $1 \cdot 280$ & & 1.569 & & 1.578 & \\
\hline $\mathrm{OH}$ & $3 \cdot 354$ & 3.35 & $3 \cdot 301$ & $3-30$ & 3.166 & $3 \cdot 17$ \\
\hline
\end{tabular}

1 and 2 from Gattihosahalli, (1) from the typical fuchsite quartzite, and (2) from one of the small schistose segregations in quartzite. Analysis: $R \mathbf{J}$ Vaidya and $\mathbf{N} \mathbf{M}$ Udayashankar.

3. Fuchsite from Pointe de Bois. Analysis: D R E Whitmore (Whitmore et al 1946).

\section{Comments on the genesis and conclusions}

The observations such as: (i) the occurrence in a bedded sequence of sedimentary rocks, (ii) close association with barytes of sedimentary origin, (iii) lack of evidence of hydrothermal activity and metasomatism; (iv) nonexistence of undoubted granitic or other intrusive bodies in close association; (v) evidence of explosive volcanic activity (Sadashivaiah 1964); (vi) laminated/foliated character and simple mineralogy of the fuchsite bearing rocks and presence in them of sedimentary minerals such as kyanite, epidote and pyrite; (vii) absence of evidence of replacement relationship of fuchsite, are all suggestive of sedimentary origin of fuchsite-bearing rocks. The 

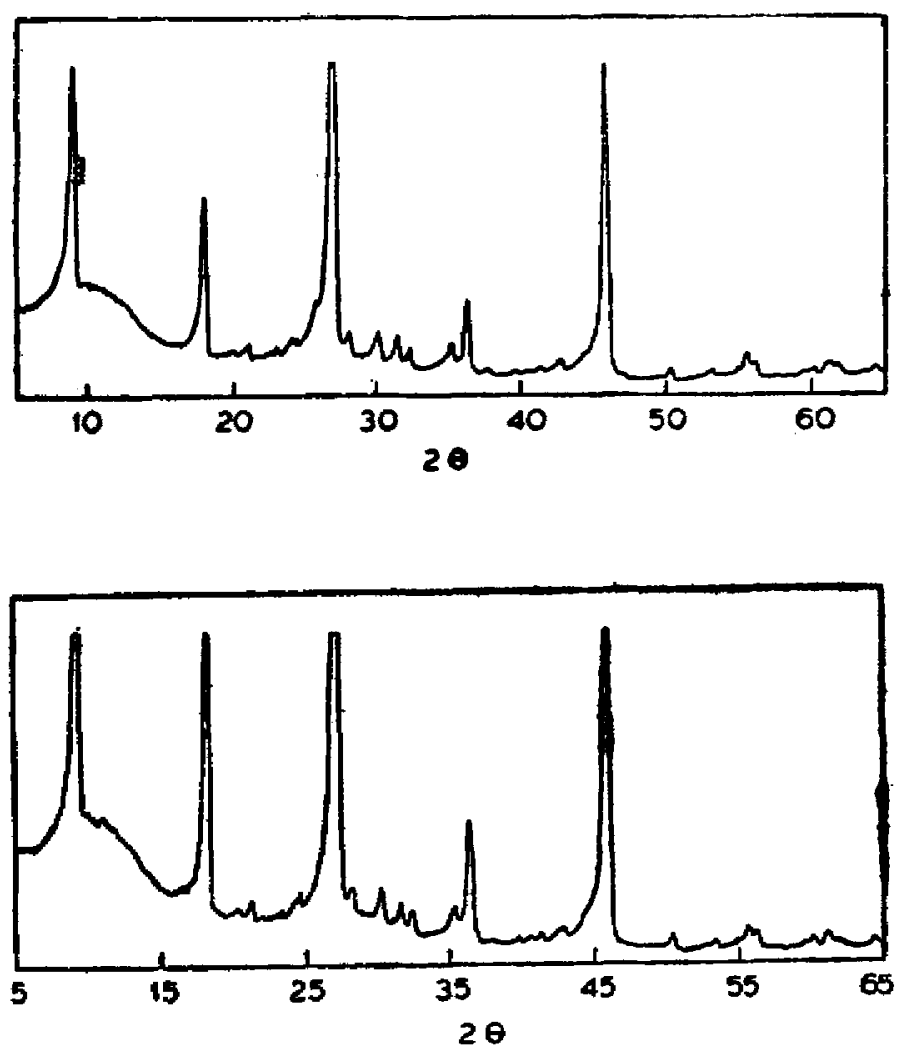

Figures 2 and 3. Powder x-ray diffraction patterns of fuchsites from quartzite and schist respectively.

components required for the formation of fuchsite were all either present in the sediment itself, possibly in the hydrolizate/shaly matter of the sandstone or those were partly or completely supplied to the rock by the volcanic exhalation which appear to have played an important role in the formation of the intimately associated baryte beds. As postulated by Anhaeusser (1976) the interbedded quartzite barite association perhaps represents terminal phase of a volcanic cycle. That relatively high pressure operated during the metamorphism of sediments, which have given rise to fuchsite-bearing rocks, is particularly indicated by the occurrence of kyanite and by the marked undulose extinction of quartz and fuchsite.

\section{Acknowledgements}

The authors are grateful to Dr M S Sadashivaiah for his keen interest and helpful suggestions. Thanks are due to Sri N M Udayashankar and Sri R J Vaidya for performing the chemical analysis of the fuchsites. The second author (KSA) expresses his indebtedness to CSIR New Delhi, for the award of a fellowship. 


\section{References}

Anhaeusser C R 1976 Econ. Geol. 7116

Deer W A Howie R A and Zussman J 1962 Rock forming Minerals (Longmans 3)

Hendricks S B and Jefferson M E 1939 Amer. Mineral. 24729

Radhakrishna B P and Srinivasaiah C 1974 J. Geol. Soc. India 15314

Sadashivaiah M S 1964 Indian Mineral 524

Sadashivaiah M S and Karisiddaiah S M 1976 J. Karnatak Univ. Sei. 2155

Whitmore D R E, Berry L G and Hawley J E 1946 Amer. Mineral 311 